Jurnal Widya Sastra Pendidikan Agama Hindu, Vol 4, No. 1, 2021

ISSN: 2656-7466

\title{
SEBUAH DESKRIPSI WACANA PUJA SARASWATI SEBAGAI REPRESENTASI KOMUNIKASI UMAT HINDU
}

\author{
I Wayan Gara \\ iwayan.gara@gmail.com
}

\begin{abstract}
ABSTRAK
Penelitian ini bertujuan untuk mengungkapkan dan memberikan sebuah deskripsi tentang hari suci puja Saraswati di pura kampus STKIP Agama Hindu Singaraja dan puja Saraswati sebagai representasi komunikasi umat Hindu, Civitas Akademika STKIP Agama Hindu Singaraja. Dalam pembahasan masalah penelitiannya digunakan teori eklektik, yang meliputi: teori azas religi, teori interaksionisme - simbolik; teori komunikasi kontekstual (personal, kelompok, dan organisasi) dalam kerangka model komunikasi (linear, interaksional, dan transaksional). Demikian pula digunakan pendekatan natural dan observasi - partisipatif dengan metode pengumpulan data melalui wawancara dan penelusuran dokumen dengan teknik rekam, pencatatan, dan fotografi. Analisis data dilakukan dengan metode reduksi data, penyajian data,, simpulan dan verifikasi hasil penelitian.

Hari suci puja Saraswati, turunnya dewi ilmu pengetahuan dan teknologi (iptek) dirayakan oleh Civitas Akademika STKIP Agama Hindu Singaraja di pura kampus setempat dalam setiap enam bulan (210 hari) sekali pada hari Saniscara Umanis Watugunung, yang pada tahun ini jatuh pada tanggal 30 Januari 2021. Rangkaian perayaan hari suci Saraswati yang jatuh pada wuku Watugunung berkaitan dengan rangkaian perayaan hari suci Pagerwesi yang jatuh pada wuku Sinta. HaL itu, ada pertaliannya dengan cerita (mitologi) Sang Watugunung yang gugur dalam perang tanding melawan dewa Wisnu.

Puja Saraswati sebagai sebuah wacana (berbingkai) ritual dewa yadnya naimitika upasana, representasi komunikasi Umat Hindu, Civitas Akademika STKIP Agama Hindu Singaraja. Hal tersebut ditandai dengan terjadinya tindakan komunikasi para partisipan, komunikator dan komunikan, antara lain: Pimpinan Lembaga berkoordinasi, bekerjasama, dan berkomunikasi dengan Jero Mangku, Manggala Pangenter Sembahyang, dan sebagainya untuk mengantarkan persembahan dan persembahyangan bersama pamedek umat sedharma agar memperoleh anugerah iptek, keselamatan, dan kebahagiaan dengan penuh rasa yakin serta bersyukur kepada Tuhan / Sang Hyang Widhi dengan berbagai manifestasiNya, terutama ista dewata, Sang Hyang Aji Saraswati.
\end{abstract}

Kata-kata / frase kunci: wacana, representasi, komunikasi, puja Saraswati, umat Hindu. 
Jurnal Widya Sastra Pendidikan Agama Hindu, Vol 4, No. 1, 2021

ISSN: 2656-7466

\title{
A DISCOURSE DESCRIPTION OF SARASWATI WORSHIP AS A REPRESENTATION OF HINDUS COMMUNICATION
}

\author{
I Wayan Gara \\ iwayan.gara@gmail.com
}

\section{ABSTRACT}

This study aims to reveal and provide a description of the sacred day of Saraswati worship at the campus temple of STKIP Agama Hindu in Singaraja and Saraswati worship as a representation of Hindus communication, the Academic Community of STKIP Agama Hindu Singaraja.The research problem discussion uses eclectic theory, which includes: the theory of religious principles, the theory of interactionism - symbolic; contextual communication theory (personal, group, and organizational) within the framework of communication models (linear, interactional, and transactional). The natural and observation - participatory approaches are used with data collection methods through interviews and document searches using recording, writing, and photographic techniques. Data analysis is carried out using data reduction methods, data presentation, conclusions and verification of research results.

The holy day of Saraswati worship, the descent of the goddess of science and technology is celebrated by the Academic Community of STKIP Agama Hindu in Singaraja at the local campus temple every six months (210 days) on the day of Saniscara Umanis Watugunung, which on this year falls on January, $30^{\text {th }} 2021$. The series of celebrations of the holy day of Saraswati which falls on the wuku Watugunung is related to the series of celebrations of the Pagerwesi holy day which falls on the wuku of Sinta. This has something to do with the story (mythology) of Sang Watugunung who died in a duel against the god Vishnu.

The Saraswati worship is a ritual discourse (framed) of dewa yadnya - naimitika upasana, a representation of Hindus communication, the Academic Community of STKIP Agama Hindu Singaraja.This is marked by the occurrence of communication actions of participants, communicators and communicants, such as: Institutional leaders coordinate, collaborate, and communicate with Jero Mangku, Manggala Pangenter Sembahyang, and so on to deliver offerings and praying with the pamedek of the worshiper community in order to obtain the gift of science and technology, safety, and happiness with full confidence and gratitude to the God / Sang Hyang Widhi with His various manifestations, especially the ista dewata, Sang Hyang Aji Saraswati.

Key words/phrases: discourse, representation, communication, Saraswati worship, Hindus.

\section{PENDAHULUAN}

Pendidikan bagi umat Hindu merupakan salah satu hal penting yang berproses dalam kehidupan di dunia ini. Hanya melalui pendidikan yang baik dan benar akan dapat mengantarkan umat manusia memiliki pengetahuan, sikap, dan keterampilan 
Jurnal Widya Sastra Pendidikan Agama Hindu, Vol 4, No. 1, 2021

ISSN: 2656-7466

yang baik dan benar pula dalam menjalani kehidupan yang berakhlak mulia, bermartabat, bijaksana, sejahtera, dan berbahagia dalam upaya untuk mencapai tujuan yang diinginkan, baik sebagai makhluk individu maupun sosial. Banyak jenis, bidang, sifat, cara, dan sebagainya yang dapat ditempuh dalam dunia pendidikan, baik formal, non formal, otodidak, teoretis, praktis; tradisional maupun modern. Artinya, dunia pendidikan pada hakikatnya adalah salah satu hak azasi manusia, tidak terkecuali bagi umat Hindu dalam memperoleh kebenaran, terutama ilmu pengetahuan dan teknologi (iptek).

Hakikat kebenaran iptek dalam Hindu adalah semuanya milik Tuhan yang Mahakuasa (Hyang Widi) dalam manifestasiNya sebagai Sanghyang Aji Saraswati, dewa penguasa "ilmu pengetahuan sosial" yang bernuansa lunak / lemah lembut, sejuk, indah sehingga beliau disimbolkan sebagai "Dewi Keindahan" yang cantik jelita, yang oleh Atmaja (2014) disebutkan sebagai simbol iptek berparadigma interpretativisme. Demikian pula manifestasi beliau pada satu sisi yang lain sebagai dewa Ganesha, pengusa "ilmu pengetahuan alam" yang bernuansa keras, kuat, sakti, dan bijak sehingga beliau disimbolkan sebagai "Dewa Kebijaksanaan", dewa iptek berparadigma positivisme. Disebutkan pula oleh Atmaja bahwa kedua simbol dewa iptek itu dinyatakan "bervisi integral mewujudkan iptek dari pembawa musibah menjadi berkah bagi umat manusia". Adapun perayaan, pemujaan, atau pemuliaan terhadap hari suci turunnya iptek, yang diperingati sebagai piodalan atau pujawali Sanghyang Aji Saraswati, khususnya di Bali dilakukan oleh umat Hindu (pandita, pinandita; ilmuwan, pelajar, musisi, artis) di pusat-pusat pendidikan, pembinaan dan pengembangan iptek, antara lain seperti di pura-pura atau parahyangan-parahyangan (jagat, desa, keluarga, dan sekolah / perguruan tinggi, pasraman, sanggar kesenian, gria pandita, dan jero / puri para pinandita). Sehubungan dengan perayaan turunnya iptek dimaksud bahwa proses dalam perolehannya mesti dilakukan melalui beragam ajaran Hindu, antara lain: Catur Asrama dengan Sadana Guru Kula (disiplin Pasraman), Catur Guru, Tri Pramana, dan Upanisad.

Dalam kaitan dengan persembahyangan bersama pada hari raya Saraswati di pura kampus STKIP Agama Hindu Singaraja, penulis sangat tertarik mengangkat sebuah peristiwa persembahyangan dimaksud dalam perspektif komunikasi. Adapun studi ini diberi judul "Sebuah Deskripsi Puja Saraswati sebagai Representasi Komunikasi Umat Hindu". Terdapat dua masalah yang ingin dibabahas, yakni (1) hari suci puja Saraswati di pura kampus STKIP Agama Hindu Singaraja dan (2) puja Saraswati sebagai representasi komunikasi umat Hindu, civitas akademika STKIP Agama Hindu Singaraja.

Pembahasan terhadap masalah penelitian seperti tersebut di atas terbatas dan terfokus pada puja Saraswati di pura kampus STKIP Agama Hindu Singaraja dan puja Saraswati sebagai representasi komunikasi umat Hindu, civitas akademika STKIP Agama Hindu Singaraja. Tujuan studi ini untuk mengungkapkan hari suci puja Saraswati di pura kampus STKIP Agama Hindu Singaraja dan puja Saraswati sebagai representasi komunikasi umat Hindu, civitas akademika STKIP Agama Hindu Singaraja. Manfaatnya secara teoretis dapat menambah wawasan keilmuan sosial, budaya, dan keagamaan pada umumnya dan keagamaan Hindu, civitas akademika STKIP Agama Hindu Singaraja - Bali pada khususnya. Manfaatnya secara praktis bahwa hasil 
Jurnal Widya Sastra Pendidikan Agama Hindu, Vol 4, No. 1, 2021

ISSN: 2656-7466

penelitian ini dapat dipakai sebagai salah satu referensi, rujukan, atau acuan dalam studi keagamaan Hindu, puja Saraswati, baik yang dilakukan secara personal maupun bersama-sama umat se-dharma.

\section{HASIL DAN PEMBAHASAN}

Pembahasan terhadap permasalahan yang timbul dalam penelitian ini meliputi: (1) hari suci puja Saraswati di pura kampus STKIP Agama Hindu Singaraja dan (2) wacana puja Saraswati sebagai representasi komunikasi umat Hindu, civitas akademika STKIP Agama Hindu Singaraja.

\section{Hari Suci Puja Saraswati}

Kata "Saraswati" berasal dari bahasa Sanskerta, yang terdiri atas kata saras yang berasal dari urat kata $s r$ 'mengalir, terus-menerus mengalir, mata air' dan kata wati 'yang memiliki'. Dengan demikian, Saraswati berarti sesuatu yang memiliki sifat mengalir, mata air (kehidupan, ilmu pengetahuan). Dalam Weda disebutkan bahwa Saraswati sebagai sebuah nama dewi sungai dan dewi ucap, ilmu pengetahuan atau kebijaksanaan. Demikian pula di dalam Purana, Dewi Saraswati disebutkan juga sebagai sakti dewa Brahma, di samping sebagai dewi ilmu pengetahuan, dewi kebijaksanaan, dan dewi sungai. Terdapat beberapa nama sungai yang terkenal di India dan disebutkan dalam Weda, antara lain: Gangga, Yamuna, Saraswati, Sutudri, Purusni, Asikni, Marudvrdha, Susoma, Narmada, dan Arjikiya. Tujuh sungai di antaranya dikensal dengan nama sapta Sindhu /Gangga.

Dewi Saraswati dipuja pada hari pujawali, piodalan, atau kelahiranNya pada Saniscara Umanis Watugunung yang dikenal dengan sebutan Sanghyang Aji Saraswati, dewanya ilmu pengetahuan dan teknologi (iptek), kesenian, keindahan / kecantikan, dan kebijaksanaan. Dewi Saraswati mempunyai banyak nama menurut sifat, atribut, peran dan sebagainya, antara lain: Suyama 'sangat cantik', Subhra 'berbusana putih'; Surada 'pemberikan sari hidup', Wagiswari 'dewi kata-kata, kebijaksanaan', Bharati 'kebudayaan', Brahmi 'sakti dewa Brahma'; penganugrah kekayaan, kegembiraan, keturunan, makanan; Citrayuh, Gayatri, Maheswari, Putkari, Wagdewi, Wani, dan Winapani. Oleh karena itulah maka Dewi Sraswati digambarkan atau disimbolkan sebagai seorang wanita cantik jelita, berkulit putih, bersih; berbusana gemerlapan, berperilaku lemah lembut, bertangan empat yang masing-masing memegang wina, 'kecapi', aksamala 'tasbih', damaru 'kendang kecil', duduk / berdiri di atas bunga teratai, pustaka / lontar, buku suci'. Sering pula dilukiskan dengan beragam atribut lainnya yang dibawaNya dalam seni arca, seperti: pasa 'jerat, simpul', tri sula 'senjata tongkat bercabang tiga', sankha 'terompet kerang laut', cakram 'senjata cakra', dan sebagainya.

Dalam pemujaan Dewi Saraswati di Bali, masih dijumpai beragam gambaran, simbolik, atau sebutan seperti di atas. Umat Hindu di Bali juga meyakini aksara atau huruf sebagai perwujudan dewi Saraswati. Begitu juga keyakinan terhadap binatang cecak yang disimbolkan dalam salah satu bentuk jajan untuk sesajen (upakara) persembahan kepadaNya. Cecak adalah binatang kecil, reptile yang sangat peka. Cecak akan berbunyi ketika suasananya tenang, hening, atau suci. Artinya, memang 
Jurnal Widya Sastra Pendidikan Agama Hindu, Vol 4, No. 1, 2021

ISSN: 2656-7466

(sungguh) benar bahwa umat Hindu mesti mendekatkan diri dan memuja beliau dalam keadaan dan suasana yang tenang, hening, atau suci.

Puja Saraswati adalah kegiatan ritual Hindu yang tergolong ke dalam Dewa Yadnya (Naimitika Upasana, Yadnya, Karma Puja), yakni kurban suci yang dilaksanakan pada waktu (hari) tertentu yang diperhitungkan berdasarkan wewaran dan wuku / pawukon. Adapun pelaksanaannya di Bali juga di parahyangan kampus STKIP Agama Hindu Singaraja berlangsung setiap 210 hari (enam bulan) sekali, yang jatuh pada hari Saniscara, Umanis, Watugunung. Tradisi berupacara Dewa Yadnya merupakan bagian integral yadnya, yang terdiri atas lima golongan besar yadnya disebut Panca Yadnya, yang meliputi: Dewa Yadnya, Rsi Yadnya, Pitra Yadnya, Bhuta Yadnya, dan Manusa Yadnya. Pelaksanaan Dewa Yadnya berdasarkan waktu, terdiri atas: kurban suci setiap hari disebut Nitya Yadnya dan kurban suci dalam waktu tertentu menurut wewaran dan wuku disebut Naimitika Yadnya. Puja Saraswati merupakan salah satu sub bagian Dewa Yadnya, jenis Naimitika Yadnya menurut wewaran dan pawukon. Hal iru sangat penting bagi umat Hindu, terutama pada kalangan dunia pendidikan dan seni budaya, di samping yadnya-yadnya terkait dan terintegral lainnya, seperti: Kajeng Kliwon, Buda Kliwon; Anggar Kasih (Anggara Kliwon); Buda Cemeng (Buda Wage); Tumpek: Saniscara Kliwon wuku Landep, Wariga, Kuningan, Krulut, Uye, Wayang; Banyupinaruh (Redite Paing Sinta), Somaribek (Soma Pon Sinta), Sabuhmas (Anggara, Wage Sinta), Pagerwesi (Buda Kliwon Sinta), Galungan (Buda Kliwon Dungulan), dan Pegat Uwakan (Buda Kliwon Pahang)..

Rangkaian pelaksanaan upacara yadnya yang tergolong Naimitika Yadnya berdasarkan perhitungan waktu (hari) wewaran dan pawukon tersebut di depan, yang ternyata dominan pengambilan perhitungannya pada unsur-unsur sebagai berikut. (1) Tri Wara, yang terdiri atas: Pasah, Beteng, dan Kajeng. (2) Panca Wara, yang terdiri atas: Umanis, Paing, Pon, Wage, dan Kliwon. (3) Sapta Wara, yang terdiri atas: Redite, Soma, Anggara, Buda, Wrespati, Sukra, dan Saniscara. (4) Wuku / Pawukon, yang terdiri atas: Sinta, Landep, Ukir, Kulanyir, Tolu, Gumbreg, Wariga, Warigadean, Julungwangi, Sungsang, Dungulan, Kuningan, Langkir, Medangsia, Pujut, Paang, Keulut, Merakih, Tambir, Medangkungan, Matal, Uye, Menail, Prangbakat, Bala, Ugu, Wayang, Klau, Dukut, dan Watugunung.

Perayaan odalan Sanghyang Aji Saraswati sebagai simbolik turunnya dewa iptek pada hari Saniscara Umanis Watugunug berkaitan erat dengan serangkaian hari raya Hindu yang jatuh pada wuku Sinta, yaitu Banyupinaruh (Redite Paing Sinta), Somaribek (Soma Pon Sinta), Sabuhmas (Anggara, Wage Sinta), Pagerwesi (Buda Kliwon Sinta). Hal itu tersirat dalam cerita, mitologi Sang Watugunung. Singkat cerita bahwa Sang Watugunung yang sangat sakti mandraguna mendapat anugrah dari dewa Brahma. la dapat mengalahkan dan menguasi 29 kerajaan (Sinta hingga Dukut). Perang tanding tidak terelakkan juga terjadi dengan dewa Wisnu yang saktinya ingin dipersunting oleh Sang Watugunung atas desakan dewi Sinta sebagai istri pampasan perangnya. Akhirnya Sang Watugunung dapat dikalahkan oleh dewa Wisnu dalam awataraNya berwujud Kurma (sejenis penyu) atas bantuan pesan rahasia Bhagawan Lumanglang. Kekalahan Sang Watugunung yang badannya jatuh ke bumi bertepatan pada hari Redite Kliwon Watugunung, yang pas saat itu hari pasaran Kajeng sehingga 
Jurnal Widya Sastra Pendidikan Agama Hindu, Vol 4, No. 1, 2021

ISSN: 2656-7466

dikenal dengan sebutan Kajeng Kliwon Pamelas Tali, Watugunung runtuh. Sebelum Sang Watugunung jatuh dan terbunuh, ia sempat mohon ampun dengan sebuah permintaan, jika jatuhnya di laut agar diberikan sinar matahari yang terik sehingga tidak sampai kedinginan, sebaliknya apabila jatuhnya di darat supaya diberikan hujan sehingga tidak sampai kepanasan. Oleh karena itulah maka ciri hujan ataukah panas terik yang terjadi pada saat hari Redite Kliwon Watugunung adalah sebagai tanda permohonannya terpenuhi seperti itu. Keesoksn harinya, Soma Umanis Watugunung ia meninggal, yang disebut sebagai Candung Watang. Selanjutnya, pada keesokan harinya, Anggara Paing Watugunung, mayatnya diseret-seret lalu hal tersebut dikenal sebagai hari Paid-paidan. Keesokan harinya, Rabu Pon Watugunung, Sang Watugunung siuman, sadar diri, hidup kembali. Hal itu dilihat oleh dewa Wisnu lalu sertamerta ia dibunuh kembali sehingga hari itu disebut urip akejep, Buda urip. Pada waktu-waktu selanjutnya, Sang Watugunung berulang kali dapat hidup kembalii berkat belas kasihan dan bantuan dari Sapta Rsi, akan tetapi selalu saja secara berulang kali pula ia dibunuh oleh dewa Wisnu. Waktu terakhir kalinya, Bhagawan Sukra memohon dengan penuh rasa hormat dan memelas kepada dewa Wisnu supaya tidak ahimsa karma dan menghidupkan kembali serta mengampuni dosa-dosa Sang Watugunung. Tibalah saatnya, Dewa Wisnu berkenan atas permohonan yang memelas dari Bhagawan Sukra dan sekaligus memberinya anugerah untuk menghidupkan kembali Sang Watugunung. Terjadilah seperti yang diinginkan bahwa Sang Watugunung hidup kembali dengan penuh kesadaran bertobat untuk selama-lamanya, yang hari itu bertepatan pada Wrespati Wage Watugunung yang dikenal dengan sebutan Urip Makalantas. Pada keesokan harinya, Jumat Kliwon Watugunung, Sang Watugunung menyucikan diri yang dilanjutkan dengan melakukan tapa, brata, yoga, dan semadi untuk memohon pengampunan dosa dan anugerah ilmu pengetahuan ke hadapan Ida Hyang Widhi, yang hari ini lalu disebut Pangredanan. Oleh karena ketaatan, keteguhan, dan ketekunannya dengan penuh disiplin ia menjalankan sadana tapa, brata, yoga, dan semadi maka pada keesokan harinya, yakni Saniscara Umanis Watugunung, Sang Hyang Widhi menurunkan dan menganugerahkan ilmu pengetahuan suci (Weda) ke dunia melalui manifestasiNya, dewi Saraswati. Oleh karenanya maka hari itu disebut hari suci piodalan / pujawali Hyang Aji Saraswati, dewanya iptek.

Perayaan hari suci Saraswati, turunnya iptek dapat dikaji dari berbagai sudut pandang, unsur-unsur azas religi pelaksanaan upacara yadnya, puja Saraswati menurut desa, kala, dan patra, seperti: emosi keagamaan, sistem keyakinan, umat keagamaan, sistem ritus dan upacara, dan peralatan ritus dan upacara. Sehubungan dengan hal tersebut maka penjabarannya secara ringkas berbasis representasi komunikasi umat Hindu, Civitas Akademika STKIP Agama Hindu Singaraja sebagai berikut.

\section{Puja Saraswati sebagai Representasi Komunikasi Umat Hindu}

Umat Hindu dan tidak terkecuali civitas akademika STKIP Agama Hindu Singaraja memiliki sistem keyakinan sesuai dengan ajaran Hindu yang disebut Panca Sradha, yang meliputi: Brahman, Atman, Punarbhawa, Karma Phala, dan Moksah. Kuatnya keyakinan yang dimiliki penganutnya itu tidak terlepas dari emosi 
Jurnal Widya Sastra Pendidikan Agama Hindu, Vol 4, No. 1, 2021

ISSN: 2656-7466

keagamaannya yang pantang dilanggar sebagai swadharma, yang tentunya didukung dengan keterkaitan yang terintegral dalam pengimplementasian sistem ritus dan upacara, peralatan ritus dan upacara yang realistik, konsepsi interaktiaksi simbolik, dan konsepsi komunikasi kontekstual menurut adat-istiadat pelaksanaan keagamaan Hindu setempat.

Umat Hindu, civitas akademika STKIP Agama Hindu Singaraja selalu melakukan persembahyangan pada setiap pujawali Sanghyang Aji Saraswati di pura kampus setempat, yang di area pura (parahyangan) dimaksud terdapat mandala jaba / jero (halaman luar / dalam), bale pagongan, dan beberapa bangun suci palinggih-palinggih yang secara simbolik sebagai tempat berstananya Sang Hyang Widi dan mnifestasiNya sebagai ista dewata. Ada sejumlah palingih di jeroan atau utama mandala, yakni: sebuah Padmasana, sebuah Panglurah, sebuah Piyasan dan sebuah jun taneg, sedangkan di Jaba mandala terdapat sebuah Tugu.

Pelaksanaan ritus dan upacara puja Saraswati pada setiap hari Saniscara Umanis Watugunung tentunya menggunakan peralatan ritus dan upacara berbasis aksara dan banten Saraswati, antara lain: suci, peras, panyeneng, daksina palinggih, kembang payas, kembang cane, canang sari, banten saraswati, sesayut Saraswati, sesayut segara gunung, rayunan, perangkatan putih kuning, buah-buahan, dan wangiwangian selengkapnya. Semua itu merefleksikan proses dan produk hubungan (komunikasi, interaksional simbolik) yang serasi dan harmonis dalam bingkai ajaran Hindu yang berkearifan lokal Tri Hita Karana, yakni hubungan yang seimbang, serasi dan harmonis antara sesama manusia (umat sedharma), manusia dengan lingkungan alam, dan manusia dengan Tuhan serta manifestasiNya sebagai ista dewata, Sang Hyang Aji Saraswati.

Sehubungan dengan hal tersebut di atas, penulis akan menampilkan contoh sebuah wacana puja Saraswati sebagai representasi komunikasi umat Hindu, kombinasi model linear, interaksional, transaksional, baik komunikasi personal "Manggala Lembaga" (ML) dengan Jero Mangku (JM), JM dengan Jero Mangku Istri (JMI), Pangayah Jero Mangku (PJM), "Manggala Pangenter Sembahyang" (MPS) maupun MPS yang memimpin dan mengantarkan tahapan persembahyangan bersama Pamedek (P) dalam menghubungkan sembah bhakti pamedek kepada Tuhan dengan manifestasiNya sebagai Sanghyang Aji Saraswati (ada aba-aba persembahyangan puja Saraswati akan dimulai ketika segala sesuatunya sudah dipandang siap untuk dilaksanakan).

\section{WACANA PUJA SARASWATI}

ML : Inggih Jero Mangku, durusang sampun kawitin (disampaikan dari tempat duduk jarak dekat pada posisi terdepan area persembahyangan).

JM : Inggih, matur suksma (prosesi upacara dimulai dengan merapalkan mentra pemujaan dan persembahan banten Saraswati yang diiringi bunyi genta serta pamedek melantunkan nyanyian kidung / kekawin).

Om puspa danta ya namah (bunga dimasukan ke dalam sangku berisi tirta). 
Jurnal Widya Sastra Pendidikan Agama Hindu, Vol 4, No. 1, 2021

ISSN: 2656-7466

Om agnir, jyotir, Om dupam samar payami (menyan dimasukan ke dalam pasepan).

Om kung kumara wijaya, Om phat (beras kuning dimasukkan ke dalam sangku).

Om Saraswati namostubhyam, warade kama rupini, siddhir astam karaksami, siddhir bhawantu me sadam (artinya: Ya Tuhan pujaanku, kepadaMu yang bergelar Saraswati yang berwajah cantik, indah berkuasa dan mempengaruhi kami semua, selalu berkuasa di dunia).

Om pranamya sarwa dewasacca, paratma nama wanca, rupa siddhi karoksabet, Saraswati nama wyaham (artinya: dihormati oleh semua dewa, karena diriMu adalah Tuhan yang dimuliakan, diriMu sebagai perwujudan yang Mahakuasa, kami memuliakan gelar Saraswati).

Om Brahmaputri mahadewi, Brahmanye Brahma nandini, Saraswati sajnayani, praya naya Saraswati (artinya: Jasmaninya Tuhannya, ya Dewi yang Maha Agung, Tuhanlah yang menjadi jiwa murni, diberi gelar Saraswati yang indah, mengatur batin serta mkhluk Tuhanku, Saraswati).

Om Sang Saraswati sweta warna ya namah swaha, Om Tang Saraswati rakta warna ya namah swaha, Om Tang Saraswati pita warna ya namah swaha, Om Tang Saraswati krsna warna ya namah swaha, Om Om Ing Saraswati wiswa warna ya namah swaha (artinya: demikian pujaanku kepada Saraswati yang berwarna putih, merah, kuning, hitam, dan serba warna).

Om dupa lingga ya namah, Om Ung dupa amreta ya namah, Ang Ang Brahma suka ya namah (sembah bakti Jero Mangku serangkaian menghaturkan ayaban / nganteb banten Saraswati).

Ih Kaki Sang Buta mangan mantra, Nini Sang Buta Antra-antra mwang Sang Buta Kala Dengen, aturana sarining hulun, ring Ida Sanghyang Saraswati, sira tinanggapa, adan ingsun, wehana sun kasidyanku, poma (Jero mangku matabuh arak, berem, dan air serangkaian menghaturkan ayaban / nganteb banten Saraswati).

Om Surya Candra, Hyang angaturaken sari pawitra, Hyang amuktyaken sari, Hyang atinggalaken sari, Om Rang Rang Parama Siwa Aditya ya namah (Jero Mangku menghaturkan ayaban / nganteb banten Saraswati).

Ang Ang Betari Saraswati, manusanira angaturaken tadah saji, aminta kreta nugraha siddhining mantra Ang Ang (Jero mangku menghaturkan ayaban / segehan lalu menstanakan Sanghyang Aji Saraswati pada tempat sesajen, banten Saraswati yang disertai dengan mentra sebagai berikut). 
Jurnal Widya Sastra Pendidikan Agama Hindu, Vol 4, No. 1, 2021

ISSN: 2656-7466

Om Gayestra ya namah, angadeg Betara Saraswati Guru Paduka byoh namah (prosesi ngayab banten Saraswati berakhir sampai di sini lalu dilanjutkan dengan prosesi persembahyangan bersama pamedek yang dipimpin oleh manggala pangenter sembahyang sebagai berikut).

MPS : Om Swastystu, inggih para pamedek sareng sami, saantkan Jero Mangku sampun puput ngaturang panganteb saha ngayab, sane mangkin ngiring ngaturang sembah antuk puja Tri Sandhya lan Panca Sembah.

"WACANA PUJA TRI SANDYA"

(Prosesi tahapan persembahyangan Puja Tri Sandhya dipimpin oleh Manggala Pangenter Sembahyang, sedangkan Jero Mangku mengantarkan pemujaan dengan suara genta).

Asana, 'Om Prasadha sthiti sharira Shiva suci nirmala ya namah svaha' (artinya: ya Tuhan dalam wujud Siwa, suci tidak ternoda, hamba telah duduk dengan tenang [wacana mentra hanya diucapkan di dalam hati dengan sikap tangan angranasika]).

Pranayama: Om Ang namah, Om Ung namah, Om Mang namah (artinya: ya Tuhan hamba menghirup udara, puraka; menahan nafas, kumbhaka; mengeluarkan nafas, recaka [wacana mentra hanya diucapkan di dalam hati]).

Kara sodana: Om soddha man svaha (artinya: ya Tuhan, sucikanlah tangan kiri hamba [wacana mentra diucapkan bersama-sama dengan para pamedek, sikap tangan kiri bergerak secara reflek di atas tangan kanan menengadah., Prosesi dilanjutkan lagi mengucapkan mentra dengan sikap tangan kanan di atas tangan kiri menengadah sebagai berikut]).

Om kara ati suddha mam svaha (artinya: ya Tuhan sucikanlah tangan dan hati hamba [kemudian dilanjutkan dengan memberikan aba-aba untuk memulai puja Tri Sandhya dengan sikap tangan angranasika memegang bunga dan dupa]).

Puja Tri Sandhya kakawitin, (bait-bait teks puja Trisandhya dilantunkan secara bersama-sama para pemedek dengan sikap tangan angranasika, memegang bunga dan dupa serta diiringi bunyi genta dari Jero Mangku sebagai berikut).

MPS, P, JM : Om, Om, Om bhur bvah svah, Tat savitur varenyam, Bhargo devasya dimahi, Dhyo yo nah pracodayat (artinya: ya Tuhan, kami menyembah kecemerlangan dan kemahamuliaanMu yang menguasai bumi, langit, dan sorga, semoga Tuhan menganugerahkan kecerdasan dan semangat pada pikiran kami).

Om Narayana evedam sarvam, Yad bhutam yac ca bavyam, niskalanko niranjano nirvikalpo, nirakhyatah suddho devo eko, narayanah na dvito asti kascit (artinya: ya Tuhan, semua yang ada berasal dari Tuhan, baik yang telah ada maupun yang akan ada, Tuhan bersifat gaib, tidak 
Jurnal Widya Sastra Pendidikan Agama Hindu, Vol 4, No. 1, 2021

ISSN: 2656-7466

ternoda, tidak terikat oleh perubahan, tidak dapat diungkapkan , suci, Tuhan Mahaesa, tidak ada yang kedua).

Om tvam Shivas tvam Mahadevah, Isvarah Paramesvarah, Brahma Visnus ca Rudras ca, Purusah parikirtitah (artinya: ya tuhan, engkau disebut Siwa yang menganugerahkan keselamatan, Mahadewa, dewata tertinggi; Iswara, Maha kuasa; Parameswara sebagai Maha raja adi raja; Brahma, pencipta alam semesta dan segala isinya; Rudra yang sangat menakutkan, dan sebagai Purusa, kesadaran agung).

Om papo'ham papakarmaham, papatma papasambhavah, trahi mam pundarikaksa, sabahyabhyantarah sucih (artinya: ya Tuhan, hamba ini papa, perbuatan hamba pun papa, kelahiran hamba papa, lindungilah hamba Tuhan, Tuhan yang bermata indah bagaikan bunga teratai, sucikan jiwa dan raga hamba).

Om ksamasva mam Mahadevah, sarvaprani hitankara, mam moca sarva paphebhyah, palayasva sadasiva (artinya: ya Tuhan, ampunilah hamba, Tuhan yang Maha Agung, anugerahkan kesejahteraan kepada semua makhluk, bebaskanlah hamba dari segala dosa, lindungilah hamba, ya Tuhan).

Om ksantavyah kayiko dosah, ksantavyo vaciko mama, ksantavyo manaso dosah, tat pramadat ksamasvamam (artinya: ya Tuhan, ampunilah dosa yang dilakukan oleh badan hamba, ampunilah dosa yang keluar melalui kata-kata hamba, ampunilah dosa pikiran hamba, ampunilah hamba dari kelalaian hamba).

Om Santih, Santih, Santih Om (artinya: ya Tuhan anugerahkanlah kedamaian, kedamaian, kedamaian selalu)

"WACANA PANCA SEMBAH"

(Manggala pangenter sembahyang berkoordinasi dan berkelaborasi dengan Jero Mangku dalam memberikan aba-aba kepada para pamedek agar siap dengan perlengkapan sesembahyang Panca Sembah untuk disucikan terlebih dahulu, seperti bunga, kawangen, dan dupa yang diiringi dengan mentra sebagai berikut).

Om puspa dantaya namah (artinya: ya Tuhan, mohon sucikan bunga persembahan hamba).

Om Ang dupa dipastra ya namah svaha (artinya: ya Tuhan, ya Brahma, sucikanlah langkah kami ini dengan ketajaman sinarMu [mentranya hanya diucapkan di dalam hati lalu mulai dari prosesi ini dan untuk selanjutnya, Jero Mangku yang merapalkan mentranya yang diiringi dengan bunyi 
Jurnal Widya Sastra Pendidikan Agama Hindu, Vol 4, No. 1, 2021

ISSN: 2656-7466

genta dan Manggala Pangenter Sembahyang yang mengantarkan tahapan pelaksanaan Panca Sembah]).

Kapertama, sembah puyung, durusang (mantra):

Om Atma tatvatma suddha mam svaha (artinya: Om Atma, atmanya kenyataan ini, bersihkanlah hamba).

Kaping kalih, sembah ring ista dewata, Sanghyang Shiwa Raditya nganggen sekar petak, inggih durusang (mantra):

Om Adityasya paran jyoti, rakta teja namostute, sveta pangkaja madhyasta, Bhaskaraya namo 'stute (artinya: ya Tuhan, sinar Sang Hyang Surya yang Maha hebat, Engkau bersinar merah, kami memujaMu, Engkau yang berstana di tengah-tengah teratai putih, hormat kepadaMu, pencipta sinar berkilauan).

Kaping tiga, sembah ring Ida Sanghyang Widi pinaka ista dewata Sanghyang Aji Saraswati, sesuhunan, betara-betari sinamian, masrana kawangen taler kangkat ngangge sekar warna-warni (mantra):

Om nama deva adhisthanaya, sarva vyapi vai sivaya, padmasana ekapratisthaya, ardhanaresvaryai namo namah (artinya: ya Tuhan yang mahaesa, yang bersemayam pada tempat yang sangat luhur, kepada Sanghyang Siwa yang sesungguhnya berada di mana-mana, yang bersemayam pada tempat duduk dari bunga teratai, kepada Ardhanareswari [Tuhan yang Mahaesa] hamba memujamu).

Kaping pat, sembah nunas panugrahan ring Ida Sanghyang Widi pinaka Ista dewata sane mapica panugrahan, masrana kawangen taler kangkat ngangge sekar warna-warni (mantra):

Om anugraha manohara, dewa dattanugraha, arcanam sarva pujanam, namah sarvanugrahaka; Deva devi maha siddhi, yajnanga nirmalatmaka, laksmi siddhiscadirghayuh, nirvighnasukha vrddhisca (artinya: ya Tuhan, Engkau yang menarik hati pemberi anugerah, anugerah pemberian dewata yang Maha agung, pujaan semua pujaan, hormat bakti hamba padaMu, pemberi semua anugerah).

Kaping lima, sembah puyung malih pisan (mantra):

Om Deva suksma paramacintyaya namah svaha (artinya: ya Tuhan, hormat kepada dewata yang tidak terpikirkan yang Maha tinggi yang gaib).

"MOHON TIRTA DAN BIJA"

(Selesai menghaturkan Panca Sembah dilanjutkan dengan mohon tirta dan bija yang diiringi kidung / kekawin serta mentra matirta dan mabija; Jero Mangku memercikkan tirta pada semua palinggih, banten, dan para pamedek yang dibantu oleh Jero Mangku Istri dan Pangayah Jero Mangku sebagai berikut). 
Jurnal Widya Sastra Pendidikan Agama Hindu, Vol 4, No. 1, 2021

ISSN: 2656-7466

JM, JMI, PJM: siratin dumun ring palingih-palinggihe lan banten ayaban makasami, wau raris tirtane kapica ring pamedek maka sareng sami mangda sapisanan puput (Jero Mangku menugaskan Jero Mangku Isti dan Pangagayah Jero Mangku untuk membantu mengedarkan tirta dan bija)

"Matirta dan mabija" (Jero Mangku memberikan tirta dan bija kepada pamedek yang diiringi dengan mentra sebagai berikut).

Om Budha maha pavitra ya namah, Om Dharma maha tirta ya namah, Om Sang Hyang maha toya ya namah (mantra yang kedengaran terucap saat Jero Mangku memercikkan tirta tiga kali).

Om Brahma pavaka, Om Visnu mrta, Om Isvara (mentra yang kedengaran terucap saat Jero Mangku menuangkan tirta ke tangan pamedek untuk diminum sebanyak tiga kali).

Om Siwa sampurna ya namah, Om Siwa paripurna ya namah, Om Parama Siwa suksma ya namah (mentra yang kedengaran terucap saat Jero Mangku menuangkan tirta ke tangan pamedek untuk mencuci muka sebanyak tiga kali).

: Tiang nunas bijane Jero Mangku (bija diterima oleh pamedek lalu dipasang di dahi, pangkal tonggorokan, dan ditelan yang diiringi dengan mentra yang hanya diucapkan di dalam hati, yang terkadang Jero Mangku terdengar sudah merapalkan itu sekalian saat memberikan pamedek tirta sebagai berikut).

Om sryam bhavantu (artinya: ya Tuhan, semoga kebahagiaan meliputi diri hamba [bija dipasang di dahi]).

Om sukham bhavantu (artinya: ya Tuhan, semoga kesenangan selalu datang pada hamba [bija dipasang di pangkal tenggorokan]).

Om purnam bhavantu (artinya: ya Tuhan, semoga segala kesempurnaan meliputi hamba [bija ditelan]).

JM : Inggih pamedek sareng sami, ngiring puputang rauh driki dumun antuk nguncarang parama santi (semua pamedek mengucapkan mantra dan setelah itu nglungsur dan nunas lungsuran lalu pulang ke rumah masingmasing).

Om Santih, Santih, Santih Om (artinya: ya Tuhan anugerahkanlah kedamaian, kedamaian, kedamaian selalu).

Studi ini diorientasikan pada model komunkasi, representasi komponenkomponen komunikasi, yaitu deskripsi ideal yang didibutuhkan untuk terjadinya komunikasi seperti wacana sebagai realitas teks dan konteks puja Saraswati tersebut di atas. Komunikasi yang tercermin pada wacana dimaksud menggambarkan komunikasi 
Jurnal Widya Sastra Pendidikan Agama Hindu, Vol 4, No. 1, 2021

ISSN: 2656-7466

sebagai suatu proses yang dinamis, yang unsur-unsurnya saling berhubungan dan dapat diidentifikasikan. Demikian pula deskripsi dilakukan terkait dengan representasi komunikasi puja Saraswati dalam perspektif Tri Hita Karana.

Ritual puja Saraswati pada tahun ini jatuh pada tanggal 30 Januari 2021 (Saniscara Umanis Watugunung). Perayaannya dilakukan dengan khidmat oleh umat Hindu, Civitas Akademika STKIP Agama Hindu Singaraja di pura kampus setempat. Terdapat sebuah realitas peristiwa komunikasi seperti tersirat dalam wacana puja Saraswati. Hal itu akan dijabarkan secara singkat menurut model komunikasi Lasswell (1948), yang meliputi unsur-unsur: komunikator (who, source, sender, encoder), pesan (say what, message), media (in Which channel), komunikan (to whom, receive, decoderr), dan efek (with what effect) sebagai berikut.

Umat Hindu, Civitas Akademika STKIP Agama Hindu Singaraja sudah biasa melaksana perayaan dan puja Saraswati dalam setiap enam bulan sekali di pura kampus setempat. Adapun ritual puja Saraswati sebagai representasi komunikasi umat Hindu dimaksud melibatkan para pelaku, terutama komunikator dan komunikan seperti yang tersirat dalam wacana puja Saraswati tersebut di depan, antara lain: ML, MPS, P, PJM, dan terimplisit partisipan (komunikan) "Om, Sang Hyang Widh" dan berbagai personifikasiNya sebagai ista dewata", simbolik perwujudan aksara / upakara Saraswati, dan bangunan suci pura, palinggih-palinggih, dan atribut lainnya di lingkungan suci pura setempat (SHW). Dalam puja Saraswati kali ini, komunikator ML adalah Dr. Drs. I Wayan Suwendra, S.Pd., M.Pd; Komunikator JM adalah Drs. I Ketut Rupa, M.Ag; komunikator MPS adalah I Putu Ari Sudiada, S.Pd., M.Pd; Komunikan JMI adalah Dra. Nyoman Suastini, M.Ag; Komunikan P adalah beberapa personal / perwakilan dari unsur yayasan dan anak-anak panti asuhan Yayasan Dana Punia kabupaten Buleleng; para dosen, para pegawai, para mahasiswa semester ganjil 2020 / 2021 dari semua prodi (Pendidikan Agama Hindu, Penerangan Agama Hindu, Pendidikan Bahasa Inggris, dan Pendidikan Olah Raga dan Kesehatan), dan beberapa siswa SMK TI Bali Global Singaraja. Komunikan khusus yang tidak kasat mata adalah SHW, seperti tersirat di dalam wacana mantra puja Saraswati, wacana mantra puja Tri Sandya, wacana mantrs Panca sembah, antara lain: "Om" sebagai "Ista Dewata" (Saraswati, Brahma, Wisnu, Narayana, Mahadewa, dan Aditya). Beliau yang berstana secara simbolik pada aksara / banten Saraswati, pura kampus setempat dengan beragam palinggih, bangunan suci, dan atributnya.

Berdasarkan realitas wacana sebagai teks dan konteks puja Saraswati tersebut di atas tampaknya seperti sederhana, akan tetapi muatan yang terkandung di dalamnya sangat kompleks. Tenuan yang sangat menarik perhatian dalam wacana puja Saraswati terdapat tipe komunikasi berbingkai. Artinya, wacana puja Saraswati menyiratkan adanya beberapa tipe dan model komunikasi dalam satu bingkai komunikasi. Terdapat tiga tipe komunikasi, yakni komunikasi organisasi, komunikasi kelompok, dan komunikasi personal. Begitu pula terdapat tiga model komunikasi, yakni model komunikasi linear (satu arah), model komunikasi interaksional (dua arah), dan model komunikasi transaksional (multi arah). 
Jurnal Widya Sastra Pendidikan Agama Hindu, Vol 4, No. 1, 2021

ISSN: 2656-7466

Tipe I, komunikasi organisasi, yang partisipannya meliputi seluruh $\mathbf{P}$, terutama civitas akademika yang bernaung pada lembaga STKIP Agama Hindu Singaraja; yang di dalamnya termasuk ML, JM, MPS, JMI, PJM, dan SHW. Tipe II, komunikasi kelompok, yang partisipannya meliputi seluruh $\mathbf{P}$ dari elemen pengurus yayasan dan anak-anak panti asuhan Dana Punia kabupaten Buleleng, elemen SMK TI Bali Global Singaraja, dan elemen PJM. Tipe III, komunikasi personal, yang partisipannya meliputi seluruh $\mathbf{P}$ yang berasal dari semua elemen yang terlibat dalam persembahyangan bersama, puja Saraswati di pura kampus STKIP Agama Hindu Singaraja pada umumnya. Komunikasi personal secara khusus tampak dari elemen JM yang nganteb, ngayab, dan memercikkan tirta yang dibantu oleh JMI dan PJM dalam upacara puja Saraswati. Demikian pula MPS yang memimpin tahapan sebahyang bersama $\mathbf{P}$ dalam puja Tri Sandya dan Panca Sembah, yang berkoordinasi, bekerjasama, dan berkolaborasi dengan JM. Jadi, tipe komunikasi personal tersirat secara umum dalam tindakan komunikasi yang dilakukan oleh $\mathbf{P}$ masing-masing ketika menghubungkan diri bersembahyang, menghaturkan bakti kepada SHW, simbolik bangunan suci palinggihpalinggih dan atribut terkait lainnya di pura setempat serta simbolik aksara / banten Saraswati. Semua itu mencerminkan hubungan (komunikasi) yang serasi, seimbang, dan harmonis dalam bingkai Tri Hita Karana.

Dalam Sebuah wacana komunikasi puja Saraswati yang berbingkai seperti tersebut di depan, tampak terselip jenis komunikasi "khas". JM, baik sebagai personal maupun pandita menghubungkan diri, nganteb, dan ngayab persembahan umat kepada SHW. Hal tersebut pada hakikatnya adalah komunikasi (linear, satu arah) antara JM terhadap SHW, seperti yang tersirat pada wacana mantra puja Saraswati, simbolik aksara / banten Saraswati, dan simbolik pura / palinggih-palinggih serta segenap pendukung lingkungan area pura yang suci, yang di dalamnya termasuk $\mathbf{P}$ yang sudah bersih dalam persembahyangan puja Saraswati. Demikian halnya MPS melakukan tindakan komunikasi dalam memimpin dan mengantarkan tahapan persembahyangan $\mathbf{P}$ melalui puja Tri Sandhya dan Panca Sembah. Adapun "wacana besar" puja Sraswati itu juga menyiratkan hubungan tidakan komunikasi yang kompleks, bertipe komunikasi kelompok dan komunikasi organisasi; bermodel komunikasi dua arah (interaksional) dan bermodel komunikasi multi arah (transaksional), yang tercermin pada interaksi antara ML dengan JM, JM bersama JMI dan PJM, JM bersama MPS dan $\mathbf{P}$, dan $\mathbf{P}$ dengan SHW.

Pada hakikatnya, teks puja Saraswati secara kasat mata (endofora) terdapat komunikator yang langsung berkomunikasi dengan komunikan saat menjelang dan berlangsungnya upacara puja Saraswati dimaksud, antara lain: ML melakukan tindakan komunikasi mempersilakan upacara puja Saraswati dimulai kepada JM lalu JM menanggapi untuk memulai upacaranya, baik melalui tindakan komunikasi verbal dan non verbal yang singkat tereksplisit dan terinplisit, baik melalui proksemik jarak dekat, paralingual yang halus, kinesik yang santun, maupun kronesik yang segera tanggap melaksanakan swadharma nganteb dan ngayabang banten Saraswati. Setelah itu, JM melakukan tindakan komunikasi dengan MPS sedemikian rupa, baik secara verbal maupun non verbal yang tereksplisit dan terimplisit. Selanjutnya, MPS melakukan tindakan komunikasi dengan $\mathbf{P}$ seperti yang terlihat pada wacana puja Saraswati 
Jurnal Widya Sastra Pendidikan Agama Hindu, Vol 4, No. 1, 2021

ISSN: 2656-7466

tersebut di depan, sementara itu, ada beberapa di antara $\mathbf{P}$ yang samar-samar terdengar menyahut "inggih" di sela-sela ajakan tegas MPS / JM dalam melakukan rangkain upacara puja Saraswati . Pada satu sisi yang lain, terdapat pula beberapa komunikator yang tidak kasat mata (eksofora). Sesungguhnya mereka juga telah berkomunikasi dan relatif telah memahami, menguasai, serta terbiasa dengan tupoksi kepanitaannya, yang tindakan komunikasinya hanya ditandai dengan gestur, mimik, perilaku, tindakan atau perilaku tertentu saja lalu secara reflek bisa menjalankan segala sesuatunya menurut ruang dan waktu pelaksanaan puja Saraswati dimaksud, antara lain: JMI, PJM, dan P, bahkan yang tanpa disadari atau terasa, sesekali terjadi silang peran, baik sebagai komunikator maupun komunikan dalam melaksanakan tupoksinya sedemikian rupa untuk kelancaran pelaksanaan puja Saraswati. Hal itu bisa terjadi karena sebelumnya mereka telah memahami, menguasai, dan terbiasa dengan tupoksinya masing-masing serta sudah berkoordinasi, bekerjasama, atau berkolaborasi mulai dari sebelum berlangsungnya puja Saraswati. Dengan demikian, setiap orang sudah tahu dan mesti segera tanggap dengan tupoksinya lalu dijalankan masingmasing terkait dengan pelaksanaan puja Saraswati.

Sejumlah pesan (informasi) terkandung dalam wacana puja Saraswati, seperti tampak pada tindakan komunikasi (ML, JM, MPS, P JMI, PJM, dan SHW) pada wacana puja Saraswati bermedia komunikasi verbal dan non verbal; berbahasa budaya Bali, dan mantra-mentra pemujaan, nganteb, atau ngayab berbahasa Sanskerts tersebut di depan. Pada intinya, ML sebagai representasi Ketua Lembaga STKIP Agama Hindu Singaraja yang punya hajatan dalam perayaan hari suci pujawali Sang Hyang Aji Saraswati dan $\mathbf{P}$, yakni semua pihak yang mendukung perayaan ini sangat berkepentingan, berharap, dan mengambil perannya atau tupoksi organisatoriknya masing-masing secara tulus ikhlas dalam persembahyangan bersama demi kelancaran jalannya upacara yadnya Saraswati. Tentunya $\mathbf{P}$ sangat yakin atas dampak dapat melakukan persembahyangan bersama itu. $\mathbf{P}$ merasa bersyukur dan relatif tenang dengan harapan yang besar akan mendapatkan anuegrah iptek serta keselamatan lahir - batin dari Sang Hyang Widi pada umumnya dan ista dewata, Sanghyang Aji Saraswatipada khususnya.

\section{KESIMPULAN}

Berdasarkan pembahasan masalah tersebut di depan maka dapat disimpulkan sebagai berikut bahwa hari suci puja Saraswati, turunnya dewi ilmu pengetahuan dan teknologi (iptek) dirayakan oleh Civitas Akademika STKIP Agama Hindu Singaraja di pura kampus setempat dalam setiap enam bulan (210 hari) sekali pada hari Saniscara Umanis Watugunung, yang pada tahun ini jatuh pada tanggal 30 Januari 2021. Rangkaian perayaan hari suci Saraswati yang jatuh pada wuku Watugunung berkaitan dengan rangkaian perayaan hari suci Pagerwesi yang jatuh pada wuku Sinta. HaL itu, ada pertaliannya dengan cerita (mitologi) Sang Watugunung yang gugur dalam perang tanding melawan dewa Wisnu. Puja Saraswati sebagai sebuah wacana ritual dewa yadnya (naimitika upasana) merupakan representasi komunikasi Umat Hindu, Civitas Akademika STKIP Agama Hindu Singaraja. Hal tersebut ditandai dengan terjadinya tindakan komunikasi para partisipan, komunikator dan komunikan seperti tersirat dalam 
Jurnal Widya Sastra Pendidikan Agama Hindu, Vol 4, No. 1, 2021

ISSN: 2656-7466

wacana puja Saraswati tersebut di depan, antara lain: Pimpinan Lembaga berkoordinasi, bekerjasama, dan berkomunikasi dengan Jero Mangku, Manggala Pangenter Sembahyang, dan sebagainya untuk mengantarkan persembahan dan persembahyangan bersama pamedek umat sedharma agar memperoleh anugerah iptek, keselamatan, dan kebahagiaan dengan penuh rasa yakin serta bersyukur kepada Tuhan / Sang Hyang Widhi dengan berbagai manifestasiNya, terutama ista dewata, Sanghyang Aji Saraswati.

\section{DAFTAR PUSTAKA}

Adnyana, I Nyoman Mider, 2012. Arti dan Fungsi Banten sebagai Sartana Persembahyangan. Denpasar: Pustaka Bali Post.

Atmaja, Nengah Bawa. 2014. Saraswati dan Ganesha sebagai Simbol Paradigma Interpretativisme dan Positivisme: Visi Integral Mewujudkan Iptek dari Pembawa Musibah Menjadi Berkah bagi Umat Manusia. Denpasar: Pustaka Larasan Bekerjasama dengan IBIKK BCCC Undiksha Singaraja dan Universitas Hindu Indonesia.

Dwipayana, Anak Agung Ngurah, 2013. Menyembah Simbol Merupakan Realisasi Brahman, Bukan Menyembah Berhala. Surabaya: Paramita.

Ginarsa, Ktut. 2007. Sajian Upacara Lahirnya Sanghyang Aji Saraswati. Denpasar: CV. Kayumas Agung.

Kaler, I Gusti Ketut. 1983. Tuntunan Muspa. Denpasar: Guna Agung.

Keriana, I Ketut. 2010. Prosesi Upakara dan Yadnya. Ubud: Buda Kliwon Pahang.

Koentjaraningrat, 1980. Pengantar IImu Antropologi. Jakarta: Rineka Cipta.

Maswinara, I Wayan, 1996. Panca Sraddha. Surabaya: Paramita.

Miles dan Hubermen, 1984. Analisis Data Kualitatif. Terjemahan oleh Tjetjep 1992.Jakarta: Ul.

Mulyana, 2005. Kajian Wacana: Teori, Metode, \& Aplikasi Prinsip-prinsip Analisis Wacana. Yogyakarta: Tiara Wacana.

Paketan, Ida Bagus Anom, 2012. Ista Dewata dan Rarahinan Agama Hindu. Denpasar: CV. Kayumas Agung.

Pandit, Narendra Dev., 1933. Weda Parikrama. Denpasar Bali: Bhawana Saraswati Publications.

Parisada Hindu Dharma Indonesia Pusat, 1978. Saraswati. Denpasar.

Parisada Hindu Dharma Indonesia - Pusat, 1992. Tri Sandhya dan Kramaning Sembah. Denpasar.

Pudja, G., 1991. Wedaparikrama. Jakarta: Hanuman Sakti.

Ritzer, George, 2011. Sosiologi, Ilmu Pengetahuan Berparadigma Ganda. Jakarta: PT RajaGrafindo.

Rudiana, Poppy dan Puji Lestari, 2019. Teori Komunikasi. Depok: Rajawali Pers. Sanjaya, Putu, 2008. Acara Agama Hindu. Surabaya: Paramita.

Soeka, Gede, 1989. Tri Rnam. Denpasar - Bali: CV. Kayumas. 
Jurnal Widya Sastra Pendidikan Agama Hindu, Vol 4, No. 1, 2021

ISSN: 2656-7466

Suastika, I Ketut Pasek. 2008. Arti dan Makna Puja Tri Sandhya - Panca Sembah, Bunga, Api, Air, Kwangen, Canang Sari, Pejati. Denpasar: CV. Kayumas Agung.

Sugiyono, 2014. Metode Penelitian Kualitatif, Kuantitatif, dan $R$ \& D. Bandung: Alfabeta.

Suhardana, K.M., 2010. Sundarigama: Sumber Sastra Rerahinan Hindu Seperti Galungan, Kuningan, Purnama, Tilem, dan Lain-lain. Surabaya: Paramita.

Sujana, I Made dan I Nyoman Susila. 2007. Keputusan Seminar Kesatuan Tafsir terhadap Aspek-aspek Agama Hindu. Surabaya: Paramita.

Suprapto, Tommy, 2019. Filsafat \& Teori Komunikasi. Yogyakarta: Pustaka Pelajar.

Suratmini, Ni Wayan. 2010. Hari Raya Saraswati, Ditinjau dari Segi Tattwa, Susila, dan Upacara. Surabaya: Paramita.

Team Penyusun, 1975. Catur Yadnya (Bhuta, Manusa, Pitra, Dewa). Kabupaten Buleleng: Yayasan Mandara Giri.

Titib, I Made, 1993. Dainika Upasana (Doa Umat Hindu Sehari-hari). Denpasar: Yayasan Guna Werddhi.

Titib, I Made. 1997. Tri Sandhya, Sembahyang, dan Berdoa. Surabaya: Paramita.

Titib, I Made. 2001. Teologi \& Simbol-simbol dalam Agama Hindu. Surabaya: Paramita.

Wiana, Ketut, 1995. Yadnya dan Bhakti dari Sudut Pandang Hindu. Denpasar: PT Pustaka Manikgeni.

Widana, I Gusti Ketut, 1997. Menjawb Pertanyaan Umat. Denpasar: Yayasan Dharma Narasha, Percetakan BP. 